\title{
Efficiency of Winter Scavengers in the Arctic
}

\author{
DAVID A. MULLEN ${ }^{1}$ and FRANK A. PITELKA ${ }^{2}$
}

\begin{abstract}
Frozen carcasses of brown lemmings, Lemmus trimucronatus, were systematically placed under the snow in various tundra habitats in the fall of 1961 (188), 1962 (201) and 1963 (205) near Barrow, Alaska. Only 8 carcasses were recovered in the following springs. Removal of the carcasses is attributed to: arctic fox (Alopex Lagopus) and red fox (Vulpes fulva); brown lemming; the least weasel (Mustela rixosa). Observations of behaviour, systematic trapping and examination of scats were used to suggest the relative importance of these consumers of lemming carrion in the order given above. The inability of investigators of lemming population cycles to find the carcasses of lemmings which die during the winter months is explained by the unusual efficiency of these species in locating and using frozen carrion during the winter months.
\end{abstract}

RÉSUMÉ. Efficacité des nécrophages durant l'hiver arctique. A l'automne de 1961, 1962 et 1963, près de Barrow, Alaska, les auteurs ont systématiquement disposé sous la neige des cadavres de lemmings bruns Lemmus trimucronatus, dans divers habitats de la toundra. Aux printemps suivants, on n'a retrouvé que 8 cadavres en tout. On peut attribuer l'enlèvement des cadavres au renard arctique (Alopex lagopus) et au renard roux (Vulpes fulva), au lemming brun et à la belette pygmée (Mustela rixosa). L'observation du comportement, le piégeage systématique et l'examen des fèces indiquent que l'importance de ces consommateurs de restes de lemmings est bien dans l'ordre énoncé plus haut. L'impossibilité pour ceux qui étudient les cycles de population chez les lemmings de retrouver les cadavres de ces animaux morts en hiver, s'explique ainsi par l'efficacité exceptionnelle que possìdent ces espèces nécrophages de retrouver et de consommer ces restes gelés.

\begin{abstract}
РЕЗЮМЕ. Жизнедеятельность животных, питающихся падалью, в зинний период в Арктике. В окрестностях г. Барроу, Аляска, в осенние периоды систематически раскладывались под снегом в рааличных условиях тундры мерзлые тушки бурых леммингов (Lemmus trimucronatus): 1961 г. (188), 1962 г. (201) и $1963 \mathrm{r}$. (205). В последующие весенние периоды было найдено только 8 тушек. Устранение тушек приписывается северной лисице (Alopex Lagopus), рыжей лисице (Vulpes fulva), бурому леммингу и ласке (Mustela rixosa). Относительный вклад этих потребителей в устранение тушек лемминга в порядке, показанном выше, основан на наблюдениях за поведением, систематическом отлове и изучении распространения этих животных. Тот факт, что исследователи популяций леммингов не находят тушки леммингов, погибших в зимний период, объясняется необычной способностью вышеуказанных видов находить мёрзлую падаль.
\end{abstract}

\section{INTRODUCTION}

Peak lemming numbers occurred at Barrow, Alaska, in the summer of 1960 (Pitelka, in press). Breeding was successful, the population shifted in favour of younger animals and the fall population was approximately 50 per cent of the 100 to 125 per acre present in the spring (Mullen 1968). Lemmings entered the fall of 1960 in apparent good health but less than 5 per cent of them survived until the spring of 1961. Failure of all attempts by the author to collect lemmings in

\footnotetext{
1Department of Biology, University of San Francisco, California, U.S.A.

'Museum of Vertebrate Zoology and Department of Zoology, University of California, Berkeley, U.S.A.
} 
the fall of 1960 suggested that most of the deaths which accounted for this decline occurred in the first 3 months of winter, September through November. Though winter temperatures were well below freezing, no frozen carcasses were found in the spring of 1961. Since avian predators are absent during the winter, the removal of lemmings or their remains must be attributed to mammalian predators. Whether the predators killed these lemmings or consumed lemmings already dead from some unknown cause is important to any examination of the factors influencing lemming populations.

Little is known, however, about the winter habits or ecology of the brown lemming, Lemmus trimucronatus, or its predators in the high arctic environment. The severe conditions under which data must be obtained and the inaccessibility of winter lemming habitat have generally limited studies of this species to the summer period. What is known about winter lemming ecology has been extrapolated from observations in the spring and from brief periods of fall trapping and has, for the most part, been conjectural and unsatisfactory. The growing volume of information concerning the ecology of the brown lemming, especially with regard to its periodic population fluctuations (Pitelka 1957, 1972; Krebs 1964; Mullen 1968), emphasizes the need for information about its winter habits. The senior author "over-wintered" at Point Barrow in 1962-63 and 1963-64 as part of a long-term study of the ecology of the brown lemming initiated by Pitelka in 1953.

This note reports on some observations and simple experiments designed to evaluate the potential effect of mammalian predation on lemming populations during the winter. Specifically, the data seek to answer the question: What happens to lemming carcasses if a severe population decline occurs during the winter? Such declines do occur, as described above, yet carcasses are rarely found during the spring thaw. It is intended here to examine only the efficiency of winter, arctic mammalian predators in locating and using carrion. More detailed accounts are available on the specific habits of individual species of arctic predators (Macpherson 1969).

\section{METHODS}

Lemming carcasses, collected during the summer months, were wired around the lower mandible with an identification tag and frozen. Frozen carcasses were placed on the tundra, after all avian predators had left the area, in the fall of 1961 (188), 1962 (201) and 1963 (205) in 3 types of experimental situations. First, carcasses were placed at 20-foot intervals along transects 1,000 feet long and 40 feet wide (approximately 1 acre in area) from which all fox and weasel scats had been removed just before the first snow. Transects were marked with wooden stakes visible above the snow in the early fall but covered with snow during most of the winter. Carcasses were pushed to the tundra surface, 12 to 36 inches from each stake, by means of a long pole to minimize the disturbance to the area; this was accomplished during a snow or wind storm so that the carcasses were almost immediately obscured. Parallel, control transects, 200 to 300 feet away, were similarly treated in all details except that no carcasses were placed along them. Control and test transects were interchanged in succeeding years. 
In a second series of experiments, carcasses were placed near 81 evenly-spaced stakes ( 9 rows of 9 stakes) in 1-acre grids from which all fox and weasel scats had been removed. Control grids were established 200 feet away and control and test grids were interchanged in succeeding years. The use of both grids and transects assured the incorporation into this study of all of the major habitat types in the Barrow area (i.e., poorly-drained marshes and well-drained level and polygonized tundra) making carcasses available in all habitats and at various snow depths.

Finally, 15 "open-top" exclosures were constructed on well-drained tundra. During the summer 1-inch mesh hardware cloth was dug into the surface of the tundra to a depth of about 3 inches and extended above the surface to a height of 2 feet. A half-inch steel pipe was driven into the tundra at each corner to form an exclosure containing 9 sq. feet of surface area. Two additional "closed-top" exclosures of the same design were completely covered with hardware cloth. Snow drifted through these exclosures but tended to be slightly deeper inside. Lemming carcasses were placed into the exclosures in the same manner described for transects and grids.

Open-top exclosures limited the use of lemming carcasses to predators travelling on the surface of the snow. Closed-top exclosures prevented all predation so that normal decomposition rates of lemming carcasses could be determined. Transects, grids and exclosures were examined as the snow melted in early spring and the remains of lemming carcasses and evidence of predators were recorded. Fox and weasel scats were collected and their contents examined and recorded.

RESULTS

\section{Recovery of carcasses}

Owing to the extremely low numbers of lemmings present in the summer of 1961 (approximately 0.5 per acre), few predators were expected to remain in the Barrow area during the following winter. It was assumed that most of the lemming carcasses offered in the fall of 1961 would be recovered, providing a control for similar experiments to be conducted during winters following summers of higher lemming numbers. The efficiency of predators in locating lemming carcasses even in this first year, however, was quite high and only 5 carcasses were recovered (Table 1). No carcasses were recovered from any of the transects in the two succeeding winters possibly because greater numbers of predators were attracted to the area by the higher population density of lemmings present in the summers of 1962 and 1963 . Though no carcass recovery was expected from the control transects, information from these cleared acreages is included in Table 1 to provide data on the normal rate of scat recovery for comparison with the test transects.

Recovery rates of carcasses offered in grid patterns were similar to those for the transects (Table 2). The only carcass recovered was found in water so it was surmised that it may have been frozen into this water throughout the winter, making it either undetectable or too difficult to remove by predators. Information from control grids is again included in Table 2 primarily for comparison of the rate of scat deposition in control and test grids. 
TABLE 1. Lemming carcasses and predator scats recovered from 1,000-foot transects.

\begin{tabular}{lcccccc}
\hline \multirow{2}{*}{ Year } & Transect & $\begin{array}{c}\text { Number of Carcasses } \\
\text { Offered }\end{array}$ & Recovered & Fox & $\begin{array}{c}\text { Scats Recovered } \\
\text { Weasel }\end{array}$ & Lemming \\
\hline $1961-62$ & I & 0 & 0 & 0 & 0 & 0 \\
& II & 0 & 0 & 1 & 0 & 0 \\
& V & 51 & 2 & 4 & 1 & 0 \\
& VI & 51 & $3^{*}$ & 8 & 1 & 1 \\
& IX & 35 & 0 & 1 & 0 & 0 \\
$1962-63$ & X & 51 & 0 & 0 & 0 & 0 \\
& IV A & 51 & 0 & 13 & 0 & 0 \\
& IV B & 0 & 0 & 0 & 0 & 0 \\
$1963-64$ & V & 51 & 0 & 5 & 0 & 0 \\
& VI & 51 & 0 & 5 & 1 & 0 \\
& IV A & 0 & 0 & 0 & 0 & 0 \\
& IV B & 51 & 0 & 4 & 0 & 0 \\
\hline Total & VI & 51 & 0 & 0 & 0 & 0 \\
\hline
\end{tabular}

*One partially consumed by lemming.

Exclosures with open tops did not prevent predation on lemming carcasses (Table 3). Since subnivean predators were prevented from entering these exclosures and only fox scats were found inside them, predation in these exclosures is attributed entirely to foxes. All of the lemming carcasses put into closed-top exclosures were recovered. Very little decomposition of these carcasses had occurred, although they were somewhat desiccated and discoloured.

TABLE 2. Lemming carcasses and predator scats recovered from 1-acre grids.

\begin{tabular}{llccccc}
\hline \multirow{2}{*}{ Year } & Grid & \multicolumn{2}{c}{$\begin{array}{c}\text { Number of Carcasses } \\
\text { Offered }\end{array}$} & Recovered & Fox & \multicolumn{2}{c}{ Scats Recovered } \\
Weasel & Lemming \\
\hline $1962-63$ & G-S & 0 & 0 & 0 & 0 & 0 \\
& G-N & 45 & 0 & 7 & 1 & 2 \\
$1963-64$ & G-S & 81 & $1^{*}$ & 2 & 0 & 0 \\
& G-N & 0 & 0 & 0 & 0 & 0 \\
\hline Total & & 126 & $1^{*}$ & 9 & 1 & 2 \\
\hline
\end{tabular}

${ }^{*}$ Found submerged in water.

TABLE 3. Lemming carcasses and predator scats recovered from exclosures of different types.

\begin{tabular}{lcccccc}
\hline Year & $\begin{array}{c}\text { Type of } \\
\text { exclosure }\end{array}$ & $\begin{array}{c}\text { Number of Carcasses } \\
\text { Offered }\end{array}$ & Recovered & Fox & $\begin{array}{c}\text { Scats Recovered } \\
\text { Weasel }\end{array}$ & Lemming \\
\hline $1962-63$ & $\begin{array}{c}\text { Open-top } \\
(1)\end{array}$ & 3 & 0 & 4 & 0 & 0 \\
$1963-64$ & $\begin{array}{c}\text { Open-top } \\
(14)\end{array}$ & 14 & 2 & 4 & 0 & 0 \\
& Closed-top & 8 & $8^{*}$ & 0 & 0 & 0 \\
\hline Total & & 25 & $10^{*}$ & 8 & 0 & 0 \\
\hline
\end{tabular}

*Eight of these were not available to predators.

( ) Number of exclosures used. 


\section{Analysis of scats}

Because of the size and coarseness of their contents, fox scats constitute the major predator artifact recovered. Weasel scats contain highly fragmented bone and hair and decompose quickly. Lemming droppings are common on the tundra and unless a large concentration of them was found near known locations of carcasses, no inference could be drawn regarding association of lemmings with evidence of predation.

The number of fox scats collected from the transects correlates well with the population density of lemmings present during the winter months. Only 14 scats were collected from 6 transects in 1962. Trapping was not undertaken in the winter of 1961-62 but trapping in the summer of 1961 produced very few lemmings and their numbers were believed to be very low the following winter. Almost double the number of scats (23) were collected in 1963 from 4 transects following a winter catch of 562 lemmings in approximately 16,500 trap days. In 1964, on the other hand, only 6 scats were collected from 4 transects after a winter catch of 31 lemmings in approximately 17,500 trap days. This correlation also held true for the test grids where 7 fox scats were recovered following the winter of 1963 whereas only 2 were found in the spring of 1964 . Only 3 fox scats were collected from control transects or grids during the entire 3 years of this study indicating that foxes spent a disproportionate amount of time near the test sites, evidentally attracted there by the lemming carcasses.

The greatest percentage (39.4) of the 60 fox scats recovered contained lemming hair and bones, this was followed closely ( 31.7 per cent) by the feathers and bones of birds, mostly from dead waterfowl. Only 1 scat $(0.9$ per cent) contained caribou hair and 2 (1.9 per cent) contained seal skin. The remaining identifiable elements included fly larvae (1.9 per cent), grasses (5.8 per cent), mosses (2.9 per cent), gravel ( 8.6 per cent) and other miscellaneous items such as paper, cloth and bird shot (6.7 per cent). No identification tags from experimental carcasses were recovered. Most of the items found indicate that foxes use a great deal of carrion in their winter diets since only lemmings could have been preyed upon directly. The miscellaneous items attest to the close association of foxes with human habitation, especially with refuse disposal areas.

\section{Predation on trap lines}

Unexpected information concerning winter predation activities was obtained from the routine trap lines established to determine the winter population density of lemmings in the Barrow area. Small museum-type mammal traps were set into holes cut into the snow to the surface of the tundra. These holes generally transected the subsnow tunnels of lemmings and were covered with a 14x14-inch sheet of plywood and snow to form a snow-free chamber. When a lemming was trapped and frozen other lemmings would gnaw on the carcass and if the traps were examined infrequently, owing to poor weather conditions, carcasses could be completely consumed in less than a week. Approximately 30 per cent of the lemmings trapped in May 1963 (24 lemmings) were consumed partly or wholly by other lemmings. The extent of this cannibalism can only be approximated 
because in many instances only a few bones were left and many lemmings were probably eaten completely leaving only the empty trap.

The characteristic gnawing of these frozen carcasses was at first believed to be due to a shrew (Sorex cinereus or Sorex arcticus) because the areas involved, usually around the eyes and ears, appeared to be too small to be caused by larger carnivores such as the weasel. The 2-mm. width of the incisor marks, however, were too wide to be those of a shrew. Subsequently, lemming feces, often red or pink in colour were found on and around the carcasses, indicating that lemmings were the consumers. The rasping marks of lemmings on the frozen carcasses showed that not only the flesh but bone and hair were also ingested.

Cannibalism of trapped lemmings began in March in both winters and increased steadily until the snow melted in late May and trapping was discontinued; this probably results from the reduced quantity of forage in the late winter months.

Though foxes commonly used the wooden trap covers as resting sites and would dig in the snow for lemmings at short distances from them, they made only 5 unsuccessful attempts to dig out trapped lemmings. Human scent associated with the traps may have confused the foxes and prevented predation on the trap lines.

\section{DISCUSSION}

The results clearly show that lemming carcasses, remaining from effects of whatever mortality factors, represent a source of nourishment efficiently exploited in the winter season not only by normal mammalian predators but also by lemmings themselves.

The arctic fox (Alopex lagopus) is present in the Barrow area throughout the winter, although it is most common in September, October and November. Their numbers in early winter appear to correlate with the abundance of lemmings inland during the previous summer and decline sharply in December, probably as a result of trapping by Eskimos and of their movement offshore onto the newly frozen pack ice.

The red fox (Vulpes fulva) also occurs near Barrow although their normally low numbers and extremely secretive habits allow them to remain unnoticed during much of the winter. A red fox den was discovered in a gravel bluff about 3 miles south of Barrow in March 1964. It appeared to have been in use for some time and was occupied continuously for the remainder of the winter. It had probably been excavated in the summer or early fall since the frozen substrate was far too hard to dig in the winter, yet no red fox had been seen in this frequently-visited area since the previous November. Unlike the less secretive arctic fox, when approached to within a half mile this fox would enter its den and remain there.

Because of their greater mobility and apparently well-developed sense of smell, arctic and red foxes probably rank as the most important users of frozen carrion. Their olfactory capabilities were demonstrated on several occasions when they were observed to dig through packed snow to recover lemming and bird remains. The behaviour was observed at temperatures well below $0^{\circ} \mathrm{F}$. and with winds of 10 to 20 knots. In one case a dried lemming carcass, filled with insect larvae from 
the previous summer, was uncovered from under 30 inches of snow by an arctic fox. Another lemming carcass was removed from under 18 inches of snow by an arctic fox. The wing tip of an eider duck was uncovered after 5 minutes of digging by a red fox from under 18 inches of snow.

Least weasels (Mustela rixosa) may also be present at Barrow throughout a winter but are most conspicuous from February to the end of May. The number of weasels collected in lemming traps coincides closely with the number of lemmings trapped. Eight weasels and 171 lemmings were collected from January to April 1963; no weasels and only 14 lemmings were collected in the same period in 1964. Because of its lower numbers, at least in the time interval of this study, the least weasel ranked as the least important user of lemming carcasses. The larger ermine (Mustela erminea) occurs at Barrow but is usually rare and was not encountered during this study.

Lemmings themselves, with their greater population density, wide distribution and observed tendency to consume carrion probably should be ranked second in importance only to the foxes as consumers of lemming carcasses. Their use of this energy source is doubtless more opportune than that of the other "predators" but nonetheless efficient in removing the remnants of a winter die-off of lemmings.

Thus evidence from this 3-year study of the use of lemming carcasses by mammalian predators and the brown lemming itself indicates that the efficiency of these combined species in the location and consumption of carrion is very good and that the intensity of predation is probably a response to the numbers of available lemmings, either living or as frozen carrion. In addition, the evidence suggests that in the winter season scavenging significantly supplements normal predation, and in the early winter may be the more important way of obtaining food. There appears to be little chance, therefore, that dead lemmings will be found in the spring following a winter die-off because of their use as food by foxes, weasels and other lemmings.

\section{ACKNOWLEDGEMENTS}

The authors gratefully acknowledge the assistance of the Office of Naval Research and its Naval Arctic Research Laboratory, Barrow, Alaska, in providing the logistic support for these experiments. The work was completed during the tenure of a U.S. Public Health Predoctoral Fellowship \#5-F1-GM-17,678-03 held by the senior author.

\section{REFERENCES}

KREBS, C. J. 1964. The lemming cycle at Baker Lake, Northwest Territories, during 1959-62. Arctic Institute of North America Technical Paper No. 15, 104 pp.

MACPHERSON, A. H. 1969. The dynamics of Canadian arctic fox populations. Canadian Wildlife Service Report Series No. 8, 52 pages.

MULleN, D. A. 1968. Reproduction in the brown lemming (Lemmus trimucronatus) and its relevance to their cycle of abundance. University of California Publications in Zoology 85: 1-24.

PITElKA, F. A. 1957. Some aspects of population structure in the short-term cycle of the brown lemming in northern Alaska. Cold Springs Harbor Symposium on Quantitative Biology 22: 237-51.

In press. Cycle pattern in lemming populations near Barrow, Alaska. 